$9-1-1994$

\title{
Crystallization of Hemoglobins II and III of the Symbiont- Harboring Clam Lucina pectinata
}

\author{
M. A. Doyle \\ Wayne State University \\ Jacqueline Vitali \\ Cleveland State University, j.vitali@csuohio.edu
}

J. B. Wittenberg

Albert Einstein College of Medicine

S. N. Vinogradov

Wayne State University

Follow this and additional works at: https://engagedscholarship.csuohio.edu/sciphysics_facpub

D A. Walz

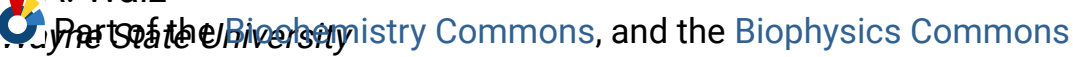

How does access to this work benefit you? Let us know!

Publisher's Statement

(C) 1994 International Union of Crystallography

\section{Original Citation}

Doyle, M.A., Vitali, J., Wittenberg, J.B., Vinogradov, S.N., Walz, D.A., Edwards, B.F.P. and Martin, P.D. (1994) Crystallization of Hemoglobins II and III of the Symbiont Harboring Clam Lucina Pectinata. Acta Crystallographica D50, 757-759.

\section{Repository Citation}

Doyle, M. A.; Vitali, Jacqueline; Wittenberg, J. B.; Vinogradov, S. N.; Walz, D. A.; Edwards, B. F.P.; and Martin, P. D., "Crystallization of Hemoglobins II and III of the Symbiont-Harboring Clam Lucina pectinata" (1994). Physics Faculty Publications. 182.

https://engagedscholarship.csuohio.edu/sciphysics_facpub/182

This Article is brought to you for free and open access by the Physics Department at EngagedScholarship@CSU. It has been accepted for inclusion in Physics Faculty Publications by an authorized administrator of EngagedScholarship@CSU. For more information, please contact library.es@csuohio.edu. 


\section{Authors}

M. A. Doyle, Jacqueline Vitali, J. B. Wittenberg, S. N. Vinogradov, D. A. Walz, B. F.P. Edwards, and P. D. Martin 
Acta Cryst. (1994). D50, 757-759

\title{
Crystallization of Hemoglobins II and III of the Symbiont-Harboring Clam Lucina pectinata
}

\author{
By M. A. Doyle and J. Vitali \\ Department of Biochemistry, Wayne State University School of Medicine, Detroit, MI 48201, USA \\ J. B. WitTENBERG \\ Department of Physiology and Biophysics, Albert Einstein College of Medicine, Bronx, NY 10461, USA \\ S. N. VINOGRADOV \\ Department of Biochemistry, Wayne State University School of Medicine, Detroit, MI 48201, USA \\ D. A. WALZ \\ Department of Physiology, Wayne State University School of Medicine, Detroit, MI 48201, USA \\ and B. F. P. Edwards and P. D. Martin* \\ Department of Biochemistry, Wayne State University School of Medicine, Detroit, MI 48201, USA
}

(Received 29 July 1993; accepted 7 March 1994)

\begin{abstract}
Diffraction data to $2.7 \AA$ resolution were measured on crystals of the homotetramers of components II and III of the cytoplasmic hemoglobin of the symbiont-harboring clam Lucina pectinata. Even though the crystallization conditions are different and the sequence homology of the two hemoglobins is only $63 \%$, the crystals are isomorphous to each other and to the heterotetramer $\mathrm{Hb}$ II/III, implying that the residues primarily involved in the intermolecular interactions and responsible for crystal cohesion may be invariant.
\end{abstract}

\section{Introduction}

The symbiont-harboring gills of the clam Lucina pectinata which inhabits the sulfide-rich coastal sediments in the Carribean contain abundant cytoplasmic hemoglobin (Read, 1966; Wittenberg, 1985) which consists of three components (Kraus \& Wittenberg, 1990). Two of these components, Hb II and $\mathrm{Hb}$ III, combine with oxygen and are unaffected by the presence of sulfide. The third, $\mathrm{Hb}$ I, combines with oxygen and in addition reacts with sulfide in the presence of oxygen to form a ferric hemoglobin sulfide. The oxygen-reactive components exhibit moderately high oxygen affinities $\left(P_{50}=0.1-\right.$ 0.2 Torr) and unusually slow rates for oxygen association and dissociation.

\footnotetext{
* Author to whom correspondence should be addressed.
}

$\mathrm{Hb}$ II consists of 150 amino acids and has a calculated molecular weight of 17476, including heme and an acetylated $\mathrm{N}$-terminal residue (Hockenhull-Johnson et al., 1991). Hb III consists of 152 amino acids and has a calculated molecular weight of 18068 , including heme and an acetylated $\mathrm{N}$-terminal residue (Hockenhull-Johnson et al., 1994). The two hemoglobins share 95 identical residues. These include a Tyr at the tenth position of the $B$ helix, which optical and EPR spectra (Kraus, Wittenberg, Lu \& Peisach, 1990) and model-building studies (Hockenhull-Johnson et al., 1991) implicate as the distal ligand to the heme iron. Hemoglobins II and III form hetero- and homomeric complexes (Kraus \& Wittenberg, 1990).

As part of our studies involving the determination of the structure of Lucina hemoglobin proteins, we report here the crystallization of the homomeric complexes of $\mathrm{Hb}$ II and $\mathrm{Hb}$ III and the preliminary $\mathrm{X}$-ray diffraction results. A preliminary X-ray diffraction study of the hetero complex of these two hemoglobins has been reported previously (Kemling et al., 1991).

\section{Experimental}

Red rectangular-shaped crystals were obtained for both hemoglobins by the hanging-drop method at $295 \mathrm{~K}$. The Hb II crystals were grown under conditions similar to those used for the $\mathrm{Hb}$ II/III complex (Kemling et al., 1991), namely, from reservoirs (1 ml) 
containing $8 \%$ saturated ammonium sulfate and $50 \mathrm{mM}$ Tris- $\mathrm{HCl} \mathrm{pH} 7.0$. The drops initially consisted of $2 \mu \mathrm{l}$ reservoir solution and $2 \mu \mathrm{l}$ protein solution containing $1.9 \mathrm{~m} M \mathrm{Hb}$ II, $0.05 \mathrm{~m} M$ EDTA and $50 \mathrm{~m} M$ phosphate buffer $\mathrm{pH}$ 7.5. The crystals of $\mathrm{Hb}$ III were obtained under different conditions, from reservoirs $(1 \mathrm{ml})$ containing $15 \%$ PEG 8000 and $500 \mathrm{mM}$ lithium sulfate. The drops initially consisted of $2 \mu \mathrm{l}$ reservoir solution and $2 \mu \mathrm{l}$ protein solution containing $1.1 \mathrm{~m} M \mathrm{Hb}$ III, $0.05 \mathrm{~m} M$ EDTA and $50 \mathrm{mM}$ phosphate buffer $\mathrm{pH}$ 7.5. These conditions were established by sparse-matrix sampling (Jancarik \& Kim, 1991) using Crystal Screen (Hampton Research) and could not be further optimized by varying the precipitant concentration. The $\mathrm{Hb}$ II crystals are generally larger than those of $\mathrm{Hb}$ III.

Data for $\mathrm{Hb}$ II were measured on a Siemens imaging proportional counter employing a three-axis camera data-acquisition system operating on a Rigaku rotating-anode $\mathrm{X}$-ray generator $(\mathrm{Cu}$ target, $1.5418 \AA$ wavelength) at $40 \mathrm{kV} 70 \mathrm{~mA}$, and using a Supper graphite monochromator; crystal dimensions: $0.60 \times 0.15 \times 0.15 \mathrm{~mm}, 2 \theta=18.0^{\circ}$, crystal-to-detector distance $=21.0 \mathrm{~cm}, 10588$ reflections with $I>\sigma$ to $2.7 \AA$ resolution, $R_{\text {sym }}$ (unweighted absolute $R$ factor based on intensity) $=6.4 \%$. The same system with the upgrade of a four-circle goniostat was used for $\mathrm{Hb}$ III; crystal dimensions: $0.35 \times 0.20 \times$ $0.10 \mathrm{~mm}, 2 \theta=18.0^{\circ}$, crystal-to-detector distance $=$ $16.0 \mathrm{~cm}, 9243$ reflections with $I>\sigma$ to $2.7 \AA, R_{\text {sym }}=$ $12.5 \%$. The difference in the $R_{\mathrm{sym}}$ values between the $\mathrm{Hb}$ II and $\mathrm{Hb}$ III crystals is probably due to their difference in size.

\section{Results and discussion}

The crystals of $\mathrm{Hb}$ II and $\mathrm{Hb}$ III are tetragonal, and systematic absences along the axes suggest that the space group is $\mathrm{P4}_{2} 2_{1} 2$ for both. They are isomorphous to each other and to the Hb II/III complex (Kemling et al., 1991). The cell constants are $a=$ $76.5, c=152.6 \AA$ for $\mathrm{Hb} \mathrm{II}$, and $a=76.8, c=$ $153.6 \AA$ for $\mathrm{Hb}$ III. The asymmetric unit probably consists of two monomers. In this case, the volume to molecular weight ratios of 3.20 for $\mathrm{Hb}$ II and 3.13 for $\mathrm{Hb}$ III are within the limits found by Matthews (1968). The observation of a dimer in the asymmetric unit suggests that the two dimers in the tetramer are related by a crystallographic twofold axis as is the case in the homotetrameric hemoglobin from Urechis caupo (Kolatkar et al., 1992).

The isomorphism of the crystals of $\mathrm{Hb} \mathrm{II} \mathrm{and} \mathrm{Hb}$ III to each other and to the Hb II/III complex is worth noting for two reasons. First, Hb III grows under dramatically different conditions from $\mathrm{Hb}$ II and $\mathrm{Hb}$ II/III. Second, $\mathrm{Hb}$ II and $\mathrm{Hb}$ III have only
$63 \%$ sequence homology and this does not necessarily imply isomorphous structures. Furthermore, it is known that vertebrate or invertebrate globins share similar tertiary structures, the myoglobin fold (Lesk \& Chothia, 1980; Bashford, Chothia \& Lesk, 1987). The sequence homology of $\mathrm{Hb}$ II and III suggests similar quaternary structures for the heterotetramer and the two homotetramers; this is confirmed by the isomorphism of the crystals. Presumably, some of the invariant residues are those involved in the subunit association. Similarly, the residues involved in the intermolecular interactions that are responsible for crystal cohesion are also likely to be invariant.

A comparison of the amino-acid sequences of the eight helices in $\mathrm{Hb}$ II and $\mathrm{Hb}$ III gives the following homology figures: $75 \% A, 75 \% B, 71 \% C, 29 \% D$, $80 \% E, 82 \% F, 44 \% G$ and $50 \% H$. The low homology of helices $G$ and $H$ between the two hemoglobins suggests that a quaternary structure similar to that of vertebrate hemoglobins is unlikely. In the latter, the $G$ and $H$ helices are in the interior of the molecule and are involved in subunit interactions. We note that other invertebrate hemoglobins differ in their quaternary structures with respect to each other and to vertebrate hemoglobins. Thus, in the dimeric and tetrameric hemoglobins from the blood clam Scapharca inaequivalvis (Royer, Love \& Fenderson, 1985; Royer, Hendrickson \& Chiancone, 1989 ), the $E$ and $F$ helices are involved in subunit interactions. In the homotetrameric hemoglobin from Urechis caupo (Kolatkar et al., 1992) the region of contact for subunits related by the molecular twofold axis is the $A / B$ turn and $E$ helix while the $G / H$ turn and $D$ helix interact at the other subunit interface.

It is noteworthy that optimal crystallization of $\mathrm{Hb}$ II occurred at approximately $0.34 M$ ammonium sulfate, which is rather low for protein crystallization. The solubility of a protein is primarily a function of its surface, which is usually covered more or less uniformly by polar groups that attract an excess of ions of opposite charge. At low ionic strength this screen of ions reduces the electrostatic free energy of the protein and consequently, the solubility of the protein increases. At high ionic strength, protein solubility decreases because the salt interacts preferentially with the water and increases its surface tension, which in turn increases the free energy of the solvent cavity that accommodates the protein (Creighton, 1993). This latter effect also explains why hydrophobic interactions are strengthened at all ionic strengths. The result we observe with $\mathrm{Hb}$ II suggests that rather than having a uniform distribution of polar groups on its surface, $\mathrm{Hb}$ II has one or more hydrophobic patches whose aggregation is favored by moderate increases in salt concentration. 
We are in the process of trying to solve these structures by the molecular-replacement method.

This work was supported in part by NSF grant DCB90-17722 (JBW) and NIH grants GM33192 (BFPE), DK30382 (DAW) and DK38674 (SNV). JBW is a Research Career Awardee 1-K6-733 of the United States Public Health Service National Heart, Lung and Blood Institute. JV was supported by NIH Training Grant T32 HL07602.

\section{References}

Bashford, D., Chothia, C. \& Lesk, A. M. (1987). J. Mol. Biol. 196, 199-216.

Creighton, T. E. (1993). Proteins: Structures and Molecular Properties, pp. 262-264. New York: W. H. Freeman.

Hockenhull-Johnson, J. D., Stern, M. S., Martin, P. D., Dass, C., Desiderio, D. M., Wittenberg, J. B., Vinogradov, S. N. \& Walz, D. A. (1991). J. Protein Chem. 10, 609-622.
Hockenhull-Johnson, J. D., Stern, M. S., Wittenberg, J. B., Vinogradov, S. N., KAPP, O. H. \& Walz, D. A. (1994). J. Protein Chem. In the press

JANCARIK, J. \& KIM, S.-H. (1991). J. Appl. Cryst. 24, 409-411.

Kemling, N., Kraus, D. W., Hockenhull-Johnson, J. D., WittenberG, J. B., Vinogradov, S. N., Walz, D. A., Edward, B. F. P. \& Martin, P. D. (1991). J. Mol. Biol. 222, 463-464.

Kolatkar, P. R., ERnst, S. R., Hackert, M. L., Ogata, C. M., Hendrickson, W. A., Merritt, E. A. \& Phizackerkey, R. P. (1992). Acta Cryst. B48, 191-199.

Kraus, D. W. \& Wittenberg, J. B. (1990). J. Biol. Chem. 265, 16043-16053.

Kraus, D. W. \& Wittenberg, J. B., Lu, J. F. \& Peisach, J. (1990). J. Biol. Chem. 265, 16054-16059.

LeSK, A. M. \& Chothia, C. (1980). J. Mol. Biol. 136, 225-270.

Matthews, B. W. (1968). J. Mol. Biol. 33, 491-502.

ReAD, K. R. H. (1966). Physiology of Mollusca, edited by K. M. Wilbur \& C. M. Yonge, Vol. 2, pp. 209-232. New York: Academic Press.

Royer, W. E., Hendrickson, W. A. \& Chiancone, E. (1989). J. Biol. Chem. 264, 21052-21061.

Royer, W. E., Love, W. E. \& Fenderson, F. F. (1985). Nature (London), 316, 277-280.

Wittenberg, J. B. (1985). Bull. Biol. Soc. Washington, 6, 301-310. 